\title{
Improving Oral Reading Fluency of Struggling ESL Readers with Assisted Repeated Reading Using Graded Readers
}

\author{
Teoh Ci Xin, Melor Md. Yunus* \\ Faculty of Education, Universiti Kebangsaan Malaysia, Malaysia
}

Received June 11, 2020; Revised July 10, 2020; Accepted August 25, 2020

\section{Cite This Paper in the following Citation Styles}

(a): [1] Teoh Ci Xin, Melor Md. Yunus, "Improving Oral Reading Fluency of Struggling ESL Readers with Assisted Repeated Reading Using Graded Readers," Universal Journal of Educational Research, Vol. 8, No. 9, pp. 4201-4212, 2020. DOI: 10.13189/ujer.2020.080947.

(b): Teoh Ci Xin, Melor Md. Yunus (2020). Improving Oral Reading Fluency of Struggling ESL Readers with Assisted Repeated Reading Using Graded Readers. Universal Journal of Educational Research, 8(9), 4201-4212. DOI: 10.13189/ujer.2020.080947.

Copyright $\bigcirc 2020$ by authors, all rights reserved. Authors agree that this article remains permanently open access under the terms of the Creative Commons Attribution License 4.0 International License

\begin{abstract}
One has to learn and master the four major language skills, namely listening, speaking, reading and writing, to be deemed proficient and fluent in the target language. In relation, reading skill is an essential language component and effective reading will allow for successful linguistic input so that comprehension, the ultimate outcome of reading skill, can be attained. Before comprehension can be established, it is important for readers to first read fluently. However, learning to read in a second or new language is often quite a challenging task. It is even more demanding for children with reading difficulties. Thus, this paper aims to explore the effectiveness of the reading intervention - assisted repeated reading using graded readers - in improving the oral reading fluency of struggling elementary-aged readers learning English as a second language (ESL). This action research based study was carried out with 7 struggling ESL readers from a primary school in the period of 30 days. The findings collected from three different data collection methods revealed that the participants were able to read with higher accuracy in word recognition and faster reading rate with improved prosodic reading. With the positive outcomes gathered from this study, it can be concluded that assisted repeated reading using graded readers did improve the oral reading fluency of struggling ESL readers. Further suggestions on how assisted repeated reading with graded readers can be adapted and applied to improve the oral reading fluency of struggling second
\end{abstract}

language readers were also given.

Keywords Elementary School, English as a Second Language, Struggling Readers, Oral Reading Fluency, Assisted Repeated Reading, Graded Readers

\section{Introduction}

The latest data for Malaysian literacy rate illustrates that adult literacy rate was $93.7 \%$ while the literacy rate for youth aged 15 to 24 was capped at $97.6 \%$ (UNESCO Institute for Statistics, 2019). Although the literacy rate of the Malaysian population has seen a steady increase in the recent years, however, it is worth noting that Malaysia ranked eighth from the bottom of the World's Most Literate Nations list out of 61 countries (Miller \& McKenna, 2016) and Malaysia dropped 9 spots from 13th place in 2017 to 22nd place in 2018 in English proficiency ranking for non-native English speakers based on the survey by the EF English Proficiency Index (EF Education First, 2018). These statistical data highlight the worrying trend in English literacy and poor reading habits among Malaysians.

The latest Malaysian Education Blueprint (Ministry of Education Malaysia, 2013) envisions that at the end of first three years primary schooling, each child will attain $100 \%$ basic literacy in English. It is significant to note that 
English Language holds the status of a second language in the Malaysian education system. The blueprint also states that children struggling with English literacy will receive additional remedial support from Literacy and Numeracy Screening Programme (LINUS 2.0) to help them keep up with their peers. However, the LINUS 2.0 programme has since stopped being conducted in primary schools. This move has left educators with greater autonomy to determine their own screening methods and provide interventions according to the varying needs of their struggling second language learners. Coupled with the alarming data that reflects the reading habits and English proficiency of Malaysians mentioned earlier, it is vital to solve the problem at its root.

Over the past decade, local ESL teachers and researchers have reviewed, tried and tested different teaching strategies to help their struggling readers read with accuracy and fluency (Ariffin \& Said, 2018; Hoon et al., 2015; Jalaludin \& Hashim, 2019; Keat \& Ismail, 2011; Maarof \& Yamat, 2010). However, there is no one single strategy that can hold claim to being the best because all learners are individuals with different learning styles and needs. This is where the purpose of this study fits into the bigger picture of assisting struggling second language learners not only in Malaysia but also other parts of the world to read fluently. Thus this study sets out to investigate whether struggling ESL readers in primary schools should be trained to read through assisted repeated reading using graded readers to improve their oral reading fluency.

\section{Literature Review}

\subsection{Automaticity Theory in the Reading Context}

The importance of developing oral reading fluency is founded in the theory of Automaticity (AT) proposed by LaBerge and Samuels (1974). In the context of reading activity, automaticity can be seen as the ability to read a text accurately and effortlessly (Morrow, et al., 2013). This is an evident skill in fluent readers but a crucial one to be developed in struggling readers. This is not an innate ability but rather it is a skill that readers can develop over time as a result of continuous extended practice. AT explains that the human brain has restricted attentional capacity for complex task like reading. The theory argues that if a person has to perform two tasks at one point of time, one of them has to be so well-learnt that it becomes automatic.

In line with this, reading is a process where the reader has to perform two complex tasks almost simultaneously, namely decoding and comprehending. Penner-Wilger (2008) highlights that when decoding is an automatic response in reading; there will more attentional resources for text comprehension and also active regulation of one's own reading process. Fluent readers are recognised as those who can decode and comprehend simultaneously while non-fluent readers direct almost all their mental energy or attentional resources to decode and consequently, this leaves very little mental space for effective text comprehension to take place (Kuhn et al., 2010; Wolf, 2018). Therefore, it is fair to say that oral reading fluency should be built in struggling readers especially, so that they can read with accuracy and automaticity and this will subsequently aid them in understanding what they read.

\subsection{Oral Reading Fluency and Its Components}

Defining oral reading fluency can be a complex task in the field of reading education. Although different definitions of reading fluency have been proposed, the central idea is that fluency means being able to read a text with accuracy, appropriate speed and expression (Reichert, 2019; Zimmerman et al., 2019). In line with this, reading of a text with accuracy, adequate rate and expression shall be the working definition for oral reading fluency in this study. The objective of this study was to investigate whether the intervention would improve the oral reading fluency of struggling readers, therefore more details in terms of the three individual components of oral reading fluency would be elaborated in line with the study by Zimmerman et al. (2019).

Accuracy in word recognition is the reader's ability to recognise, decode and produce accurate oral representation of the words in a text. Word recognition is essential for fluent and skilled reading because fluent reading of a text is marked by $95 \%$ or greater accuracy rate (Rasinski, 2011). To put simply, if a reader cannot recognise or decode words in a text, there will be no reading fluency, not to mention text comprehension. Besides word recognition accuracy, reading speed has been found to be another essential component for fluent reading (Rasinski, et al., 2011). As readers decodes faster, they focus lesser attention on word recognition during reading. Wolf and Katzir-Cohen (2001) suggest that faster word recognition is a reflection of improved reading because when word recognition is automatic, the improved reading rate will free up more cognitive capacity for text comprehension. The last significant component of reading fluency is prosody. It refers to the reader's ability to read a text orally with appropriate intonation and phrasing, expression, volume, smoothness and pace, If a reader has natural and appropriate break points while reading, it will help the reader remember the meaningful sequence of words and phrases read better for further processing in the working memory (Kuhn, et al., 2010). Simply put, prosodic reading can mean reading like normal speech. These three components of reading fluency elaborated in this section formed the basis of discussion for this study to answer the research questions.

\subsection{Repeated Reading and Its Role in the Second Language Context (L2)}

Repeated reading (RR) is not a new reading instructional tool to those in the field of language education. Originally, 
this reading instruction requires readers to read a 50-200 words passage silently and aloud for a few times until adequate speed and accuracy are attained (Frey \& Fisher, 2017). Research on RR carried out in the later years would see the emergence of different models of repeated reading such as assisted reading (oral modelling from an expert or guided practice), unassisted reading (silent reading with no modelling or independent practice), paired RR and many more. However, all the repeated reading procedures share a common goal, which is to help poor readers to reread meaningful passages until oral production of the text is fluent and flowing and meaning-making between the reader and the text can be possible. The concept that forms the premise of this study was that RR provides multiple practice opportunities for high success rate in reading as readers are exposed to a bank of quickly identified words and this repeated language exposure will result in high degree of vocabulary access, activation and overlap.

In the past decades, many L2 studies have been conducted with positive outcomes that support the efficacy of RR in improving pupils' reading accuracy and fluency. Roundy and Roundy (2009) find that the use of RR strategies improved students' fluency, reading rate score, reading-oriented self-esteem, and sense of confidence. Along parallel lines, the study conducted by Lee and Yoon (2015) find out that the method of repeated reading has positive effects on students with reading difficulties, especially at the elementary level while Fields (2019) provides beneficial findings that support primary teachers implementing repeated reading to increase reading accuracy, fluency and comprehension of their pupils. In support, Chomsky (1976) explains that rereading a text aids slow and struggling readers achieve fluency with ease due to increased motivation and self- confidence. She also highlights that these beginning readers would be able to have fluent reading of subsequent unpracticed passages with fewer practices as they evolve into self-regulated readers. All these empirical evidences mentioned earlier suggest that repeated reading is a suitable reading strategy not only for developmental readers in regular classrooms, but also for struggling L2 readers in remedial classes to help them achieve the goal of improving oral reading fluency.

\subsection{The Role of Graded Readers in Reading}

Although the method of repetition can develop linguistic intuition in pupils for language learning (McLeod, 2015), the monotonous task of re-reading a text multiple times would stretch the attention span of elementary-aged readers, resulting in boredom. Boredom often leads readers to disengage themselves from the reading process and if this behaviour persists, it would gradually become more challenging for teachers to help poor readers improve their reading skills and become independent readers (Sarroub \& Pernicek, 2016). In this case, Zhao and Poole (2017) propose that graded readers would serve as a better solution to compensate for the monotony of repeated reading.
Graded readers are books specifically written for second language readers to provide them with a reading experience at a level of fluency and comfort at par with first language reading (Nation \& Ming-Tzu, 1999). This is essential because readers need to have access to the text they read so that they remain motivated and interested in reading (Protacio \& Jang, 2016). In other words, graded readers provide the opportunity for language learners to have contact with easy reading materials containing familiar words with a mix of new vocabulary in the target language.

In addition, graded readers can be regarded as suitable reading materials for struggling readers because of the specific linguistic guidelines that the authors have to adhere to when writing the series. A graded reading scheme also consists of controlled content (restricted list of vocabulary and grammar structures) to match the ability of readers learning a second or foreign language (Day, 2018). Hill (2001) talks about the similar content and linguistic structures in the graded readers series and this enables readers to pass from one book to the next without much difficulty and regain the reading speed they achieved at the previous book. In other words, the readers can concentrate more on oral reading fluency instead of accuracy in word recognition of new vocabulary. In support, Nation (2018) also asserts that graded readers are good for vocabulary learning due to its repetitive encounters with selected words and accurate word recognition is essential for fluent reading. All these findings support the choice of reading material for the intervention in this study.

\subsection{Making Connection betweenAssisted Repeated Reading and the Development of Oral Reading Fluency in Struggling Readers}

The reading intervention chosen was assisted repeated reading using graded readers where struggling ESL readers reread passages from a selected series of graded readers with the help of a fluent English teacher. The steps of the intervention were designed based on the concept of behaviourist theory. McLeod (2015) highlights that behaviourist teaching methods like repetition can build up a linguistic intuition that is effective for pupils to use as the benchmark in establishing a threshold for language learning. In context, it was presumed that as the non-fluent participants were drilled to repeatedly read aloud the graded readers during the intervention sessions, their ability to decode and recognise words in the passages would become intuitive to the point of immediate recognition. In support, other investigations also maintain that repeated reading intervention helps to develop the reading fluency of struggling learners (Bendak, 2018; Stevens, et al., 2016). Thus, these struggling readers can decode the text more easily as they read repeatedly and improve their oral reading fluency.

Moreover, the assisted model was selected because there are certain instructional conditions that must be met for the reading strategy to be more effective in helping struggling readers. A widely acknowledged and cited meta-analysis 
by Therrien (2004) advises the following criteria to be included in the implementation of repeated reading strategy. Firstly, pupils can perform the reading intervention with an adult who reads the passage first. Secondly, it is recommended that the reading passage be read three to four times by the pupils before moving on to a new passage. The last point to be taken into consideration is that the adult accompanying the pupils should provide corrective feedback as they progress in the reading activity. All these conditions described fit the characteristics of the assisted model where a fluent English teacher would model the reading for the struggling readers. In line with Krashen's input hypothesis, exposing learners to input that is slightly beyond their current level of language ability for them to repeatedly concentrate on has clear benefits to the readers, provided that supporting conditions are present (learners would be in their zones of proximal development) like modelling from an adult teacher (Namaziandost et al., 2019; Young et al., 2015). These are the rationales behind the choice of assisted model for the reading intervention in this study.

Assisted repeated reading is also grounded in the principle of teacher-directed approach and this is in line with the concept of direct instruction. It was discovered that teacher-centered, explicit and direct instruction that involves structured materials can result in efficient learning of basic skills (Luke, 2014). In this case, the basic skill involved was oral reading fluency. To corroborate this notion, direct instruction is a useful approach for learners when they are learning materials that are difficult to grasp and slightly beyond their capacity at first (Treiman, 2018). The assisted model was selected because struggling readers that read at a lower rate need more support and practice opportunities to develop their fluency until they reach a higher reading rate where they can practise independent reading. In other words, this model provides readers that struggle the guidance and demonstration on the correct sounding of words, proper phrasing and acceptable speed for fluent reading before they can read independently.

Moreover, the participants for this study were all struggling elementary-aged ESL readers that require more support in the initial stage of reading. There is a greater need for modelling and proper demonstration. Based on the reading development scale proposed by Chall (1983), struggling readers are categorised under stage 2 of the reading scale where there is a need for direct instruction in decoding skills and wide reading of familiar and interesting materials to promote fluent reading. Chall further explains that readers at stage 2 should be read to at a level above their own independent practice to develop their language, vocabulary and concepts and their listening skill is more effective than reading. In this case, assisted repeated reading engages readers in two mediums of perception (listening and reading) which may increase the word retention skill of L2 readers in the long run (Dlugosz, 2000). In support, Lee and Yoon (2015) find that RR is beneficial in building fluency and this effect is enhanced when readers get to listen to the text being read before reading it themselves. The desirable outcome would be the eventual success of the beginning readers in segmenting the text into more appropriate chucks of information and read with fewer pauses and more voice inflection. Hence, it is fair to say that the reading intervention - assisted repeated reading is an appropriate and feasible approach to be used for struggling primary school ESL readers.

\section{Materials and Methods}

\subsection{Research Sample}

The details of the participants involved in this study are tabulated in Table 1.

Table 1. Demographic Profile of Research Participants

\begin{tabular}{|c|c|c|c|c|}
\hline Participants & Gender & Age & Race & $\begin{array}{c}\text { Unique } \\
\text { Aspects/Socioeconomic } \\
\text { status } \\
\end{array}$ \\
\hline S1 & $F$ & 9 & Indian & \multirow{7}{*}{$\begin{array}{c}\text { Low English proficiency } \\
\text { Was in literacy support } \\
\text { programme } \\
\text { Low/ below average SES }\end{array}$} \\
\hline S2 & M & 9 & \multirow{6}{*}{ Chinese } & \\
\hline S3 & $\mathrm{M}$ & 9 & & \\
\hline S4 & $\mathrm{F}$ & 10 & & \\
\hline S5 & $\mathrm{F}$ & 10 & & \\
\hline S6 & $\mathrm{M}$ & 10 & & \\
\hline S7 & $F$ & 10 & & \\
\hline
\end{tabular}

Labels are used in place of participants' real names. All the participants, specifically 3 females and 4 males, were from a Chinese primary school located in the urban area in one of the states in Malaysia. This group of participants came from 2 different age groups and they were all learning English as a second language (ESL). At the time of the study, none of the participants received direct coaching or any form of ongoing learning assistance for reading skills beyond regular instructions during English lessons. As part of their academic course, they had 150-180 minutes of English classes per week. All of them were previously under the Literacy and Numeracy Screening (LINUS) programme that is no longer being conducted in schools. They had been screened prior to the implementation of the intervention to identify potential reading problems based on the descriptors found in Chall's (1983) stages of reading development. Ideally, the participants involved in this study should be at stage 3 (9 to 13 years old) in terms of their reading development where reading is used to learn new ideas and attitudes, increase knowledge, and experience new feelings. However in reality, at the point of the study, they were still at stage 2 ( 7 to 8 years old) of the reading development scale where characteristics of this group of readers include reading simple and familiar selection of stories with increasing fluency through the consolidation of basic decoding components, sight vocabulary and contextual meaning. Hence, there was an urgent need for a reading intervention tailored to this group of struggling ESLreaders.

Additionally all the participants come from families with 
low socioeconomic status (SES). Children from low socioeconomic (SES) homes often lack conducive literacy environment and good resources for education at home, and these factors could have contributed to their exhibition of delayed letter recognition and reading difficulties as well as their limited interest in literacy (Ozernov-Palchik, et al., 2018; Vechten, 2013). During the usual English lessons in class, the characteristics mentioned can be observed in the participants involved in this study. They mostly just read along absent-mindedly or daydream when group reading is conducted. Sometimes, they just stare blankly at the reading text provided because they find it difficult to decode fast enough for fluent reading to happen successfully. Additionally, they often are not able to complete the follow up learning activities independently after reading. All these characteristics mentioned clarify how their background of low SES has contributed to the participants' inability to master basic reading skill in second language learning like oral reading fluency and their low proficiency in English.

\subsection{Materials Used}

The graded readers chosen for this study was the revised edition Ladybird Key Words Reading Scheme. Hill (2001) mentions that there are certain criteria in choosing a good graded reading scheme. The books should look attractive and well laid out; the storyline is strong and clear; the grading is even and consistent with careful language controls; the additional materials found in the books should enhance fluency; the text should be legible and it should offer chances for direct language learning. In essence, Key Words Reading Scheme (Peter and Jane) fulfills most of the criteria mentioned. Therefore, it was selected as the reading material to be used for the intervention in this study. The list of targeted vocabulary used in this study is shown in Table 2.

Table 2. Vocabulary list from the Key Words Reading Scheme

\begin{tabular}{|c|l|c|}
\hline Set & \multicolumn{1}{|c|}{ New Vocabulary } & No. Of words \\
\hline 1a, 1b, 1c & Peter, Jane, and, here, is, the, dog, likes, I, a, shop, toy, is, has, ball, tree & 16 \\
\hline 2a, 2b, 2c & $\begin{array}{l}\text { Pat, they, are, water, fun, come, it, says, have, he, look, fish, wants, no, you, some, for, this, can, jump, into, we, } \\
\text { to, go, yes, sweets, home }\end{array}$ & 27 \\
\hline
\end{tabular}

\subsection{Data Collection Procedures}

The instructional steps for the intervention are presented in Figure 1.

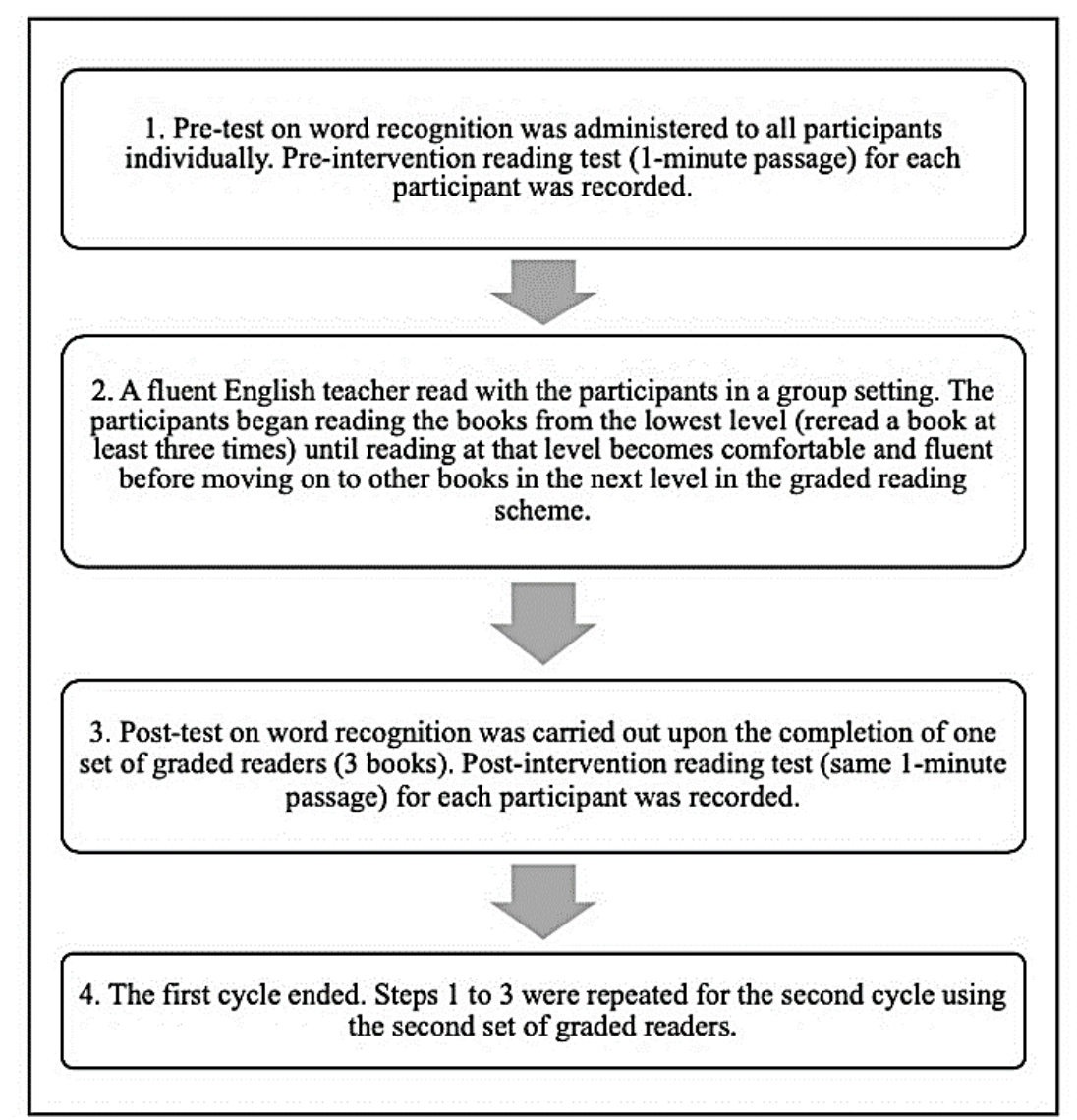

Figure 1. Instructional Steps for the Intervention 
Table 3. Pre and Post-tests Word Recognition Scores

\begin{tabular}{|c|c|c|c|c|c|c|}
\hline \multirow{4}{*}{ Participant s } & \multicolumn{3}{|c|}{ First Cycle } & \multicolumn{3}{|c|}{ Second cycle } \\
\hline & \multicolumn{3}{|c|}{ BOOK 1 (16 words) } & \multicolumn{3}{|c|}{ BOOK 2 ( 27 words) } \\
\hline & \multicolumn{3}{|c|}{ Correct words recognition } & \multicolumn{3}{|c|}{ Correct words recognition } \\
\hline & Pre & Post & Difference & Pre & Post & Difference \\
\hline S1 & $\begin{array}{c}10 \\
63 \%\end{array}$ & $\begin{array}{c}15 \\
94 \%\end{array}$ & $\begin{array}{c}5 \\
31 \%\end{array}$ & $\begin{array}{c}18 \\
67 \%\end{array}$ & $\begin{array}{c}24 \\
89 \%\end{array}$ & $\begin{array}{c}6 \\
22 \%\end{array}$ \\
\hline S2 & $\begin{array}{c}8 \\
50 \% \\
\end{array}$ & $\begin{array}{c}15 \\
94 \% \\
\end{array}$ & $\begin{array}{c}7 \\
44 \% \\
\end{array}$ & $\begin{array}{c}11 \\
41 \% \\
\end{array}$ & $\begin{array}{c}24 \\
89 \% \\
\end{array}$ & $\begin{array}{c}13 \\
48 \% \\
\end{array}$ \\
\hline S3 & $\begin{array}{c}10 \\
63 \%\end{array}$ & $\begin{array}{c}14 \\
88 \%\end{array}$ & $\begin{array}{c}4 \\
25 \%\end{array}$ & $\begin{array}{c}16 \\
59 \%\end{array}$ & $\begin{array}{c}27 \\
100 \%\end{array}$ & $\begin{array}{c}9 \\
41 \%\end{array}$ \\
\hline S4 & $\begin{array}{c}7 \\
44 \% \\
\end{array}$ & $\begin{array}{c}14 \\
88 \%\end{array}$ & $\begin{array}{c}7 \\
44 \% \\
\end{array}$ & $\begin{array}{c}7 \\
26 \% \\
\end{array}$ & $\begin{array}{c}24 \\
89 \% \\
\end{array}$ & $\begin{array}{c}17 \\
63 \%\end{array}$ \\
\hline S5 & $\begin{array}{c}9 \\
56 \%\end{array}$ & $\begin{array}{c}15 \\
94 \%\end{array}$ & $\begin{array}{c}6 \\
38 \%\end{array}$ & $\begin{array}{c}14 \\
52 \%\end{array}$ & $\begin{array}{c}27 \\
100 \%\end{array}$ & $\begin{array}{c}13 \\
48 \%\end{array}$ \\
\hline S6 & $\begin{array}{c}8 \\
50 \%\end{array}$ & $\begin{array}{c}13 \\
81 \%\end{array}$ & $\begin{array}{c}5 \\
31 \%\end{array}$ & $\begin{array}{c}9 \\
33 \%\end{array}$ & $\begin{array}{c}27 \\
100 \%\end{array}$ & $\begin{array}{c}18 \\
67 \%\end{array}$ \\
\hline S7 & $\begin{array}{c}4 \\
31 \%\end{array}$ & $\begin{array}{c}13 \\
81 \%\end{array}$ & $\begin{array}{c}9 \\
50 \%\end{array}$ & $\begin{array}{c}5 \\
19 \%\end{array}$ & $\begin{array}{c}24 \\
89 \%\end{array}$ & $\begin{array}{c}19 \\
70 \%\end{array}$ \\
\hline
\end{tabular}

\section{Findings and Discussion}

\subsection{Pre-tests and Post-tests Scores on Word Recognition}

Individually, participants were asked to read aloud the list of vocabulary (refer to Table 1) from the first set of graded readers and the scores were tabulated. This process is carried out for the pre-test and post-test in the first cycle, and then repeated in the second cycle of intervention with the vocabulary list from the second set of graded readers. Accuracy in word recognition was operationalised as the percentage of words read correctly in the tests. The scores for the word recognition tests pre and post-intervention as well as the difference in the scores for both cycles are presented in Table 3. Although none of the participants could recognise all 16 words correctly in the first cycle, it was clear that they could recognise more words correctly post-intervention. Furthermore, even though only 3 out of 7 participants could recognise all 27 words from the vocabulary list in the second cycle, it was worth nothing that further improvement could be observed in the participants after the second cycle of intervention was implemented.

\subsection{Audio Recordings of Passage Reading}

In order to validate the primary teacher-researcher's score on the Multidimensional Fluency Scale (MFS), an ESL teacher expert from another primary school was asked to independently listen and score the audio recordings of each participant's readings based on the MFS. The score of Kappa $=0.82,(p<.001)$ showed a substantial agreement between both raters (McHugh, 2012). Moreover, Moser (as cited in Zimmerman, et al., 2019) explains that the use of MFS in previous studies indicates that this prosody rubric is a reliable assessment tool for prosody with inter-rater reliability above .80 .
Table 4. Participants' Reading Rates

\begin{tabular}{|c|c|c|c|}
\hline \multirow{2}{*}{ Participants } & \multicolumn{3}{|c|}{ Reading rates (wpm) } \\
\cline { 2 - 4 } & First Cycle & Second Cycle & Difference \\
\hline S1 & 80 & 87 & $7(8 \%)$ \\
\hline S2 & 91 & 110 & $19(17 \%)$ \\
\hline S3 & 86 & 97 & $11(11 \%)$ \\
\hline S4 & 83 & 89 & $6(7 \%)$ \\
\hline S5 & 92 & 102 & $10(10 \%)$ \\
\hline S6 & 81 & 92 & $12(13 \%)$ \\
\hline S7 & 85 & 95 & $10(11 \%)$ \\
\hline
\end{tabular}

Table 5. Participants' Total Prosody Scores by Both Raters

\begin{tabular}{|c|c|c|c|c|}
\hline \multirow[b]{2}{*}{ Participants } & \multicolumn{3}{|c|}{ Total Prosody Scores } & \multirow{2}{*}{$\begin{array}{c}\text { Achievement } \\
\text { Above/Below } \\
\text { Minimum Value of } \\
10 \\
\end{array}$} \\
\hline & $1^{\text {st }}$ Rater & $2^{\text {nd }}$ Rater & Average & \\
\hline S1 & 10 & 10 & 10.0 & Above \\
\hline S2 & 16 & 16 & 16.0 & Above \\
\hline S3 & 12 & 12 & 12.0 & Above \\
\hline $\mathrm{S} 4$ & 14 & 13 & 13.5 & Above \\
\hline S5 & 16 & 15 & 15.5 & Above \\
\hline S6 & 12 & 12 & 12.0 & Above \\
\hline S7 & 16 & 15 & 15.5 & Above \\
\hline
\end{tabular}

Each participant was asked to read aloud a passage (refer to Appendix A) extracted from the first set of graded readers. The scores for reading rate and prosody were calculated and tabulated. The same procedures were repeated with another passage (refer to Appendix B) extracted from the second set of graded readers. The audio recordings in both cycles were listened to and analysed. In the present study, the standard oral reading rates by Hasbrouck and Tindal (2006) was adopted as a benchmark for analysis, which was 89 correctly read words per minute (wpm). Then, the oral reading rates for individual participant and the differences in both cycles were tabulated in table 4. In the first cycle, although only two participants (S2 and S5) achieved the targeted reading rate mentioned, the rest did manage to score reading rates that 
were very close to the goal. Nevertheless, after the second cycle of intervention, almost all the participants excluding one (S1) achieved the optimal reading rate set. Five participants (S2, S3, S5, S6 and S7) even surpassed the benchmark set at the beginning of the study. Next, the audio recordings from both cycles were analysed to score participants' prosody in reading with reference to the Multidimensional Fluency Scale (refer to Appendix C). The average scores between both raters from both cycles were tabulated in Table 5. The results indicate that all participants were progressing well in prosodic reading, scoring at or above the minimum value of 10 .

\subsection{Group Interview with the Participants}

Two questions (refer to Appendix C) were asked during the interview. The responses from the participants for the open-ended questions were analysed thematically, summarised and presented in Table 6. On a general note, the participants liked reading the graded readers because of its easy linguistic content and colourful illustrations and the modelling they got from the teacher and other participants. For instance, S1 explained that the graded readers were easy to read because of the repetitive vocabulary and phrases (“Peter and Jane 里面的字会一直重复, 容易读”) while S5 and S6 highlighted the presence of coloured graphics which makes the books reader-friendly. (我喜欢 看里面的图案, 我有时候会看图猜字的意思). S4 liked the modelling from the teacher and experienced lesser stress in reading during the intervention sessions. ( “大家 可以学老师读, 没有什么压力” ). The use of reading materials that match the ability of learners and with recurring vocabulary and structures, such as graded readers, can support their reading (Day, 2018; Hill, 2001; Nation, 2018). Additionally, it is also documented that pupils can benefit from having assistance from an adult or teacher-directed instruction to guide them in learning materials that are slightly above their current ability (Namaziandost et al., 2019; Young et al., 2015). All these empirical evidences from past studies corroborate the positive feedbacks received from the participants.

Based on the responses from the interview, S7 liked the peer teaching and learning that happened during the reading sessions ("I like to read with friend, 他会教我, 我也会教他”). This notion was supported by the other four participants. S7 also suggested the option of reading other books besides graded readers ( “可以读其他的书吗? ”). This was the similar response given by other four participants. On a side note, S4 who liked the modelling and relaxed reading environment felt they were reading the same set of graded readers for too many times ( “我觉得 我们重复读同样的书太多次了” ). It has been explained earlier that the monotonous task of re-reading a text would stretch the attention span of elementary-aged second language readers, resulting in boredom (Zhao \& Poole, 2017). With regards to this issue, teachers can allow the struggling readers to select the set of graded readers that they would like to read before starting to engage them in the reading intervention sessions. Protacio and Jang (2016) propound the importance of providing accessible reading texts that are of interest to the pupils so that they would be motivated to continue reading. In this way, the participants would not feel bored rereading the same graded readers or reading a material that is not of interest.

Table 6. Thematic Analysis of Participants' Responses for Group Interview

\begin{tabular}{|c|c|c|}
\hline Items & Answers in themes & Participants \\
\hline \multirow{4}{*}{$\begin{array}{c}\text { What do } \underset{\text { you like }}{\text { intervention? }} \text { about the } \\
\end{array}$} & $\begin{array}{l}\text { Easy and suitable reading materials with colourful } \\
\text { pictures }\end{array}$ & S1, S2, S5, S6 \\
\hline & Modelling from an expert/shared reading & S4, S5, S6, S7 \\
\hline & Peer teaching and learning & S1, S2, S3, S6, S7 \\
\hline & No stress in reading & S4 \\
\hline \multirow{3}{*}{$\begin{array}{l}\text { What do you not like about the } \\
\text { intervention? }\end{array}$} & Too many repetitions & S4 \\
\hline & Limited choices of reading materials & S3, S4, S5, S6, S7 \\
\hline & Nothing & $\mathrm{S} 1, \mathrm{~S} 2$ \\
\hline
\end{tabular}

Table 7. Overall Research Findings

\begin{tabular}{|c|c|c|c|c|c|c|c|}
\hline Participants & S1 & S2 & S3 & S4 & S5 & S6 & S7 \\
\hline $\begin{array}{c}\text { Word Recognition Accuracy } \\
\text { (\%) }\end{array}$ & 89 & 89 & 100 & 89 & 100 & 100 & 89 \\
\hline Reading Rates (wpm) & 87 & 110 & 97 & 89 & 102 & 92 & 95 \\
\hline Prosody Scores & 10.0 & 16.0 & 12.0 & 13.5 & 15.5 & 12.0 & 15.5 \\
\hline
\end{tabular}




\subsection{Overall Research Findings}

As mentioned in the earlier chapter, oral reading fluency comprises of three major elements. They are accuracy in word recognition, reading speed and prosody reading. The objective of this study was to investigate whether the intervention would improve the oral reading fluency of struggling ESL readers from elementary schools. In line with that, the oral reading fluency of the participants was evaluated in the context of the three components of the reading skill. The overall research findings are summarised in the table 7 .

The responses collected from the group interview help to triangulate the more objective results from the word recognition tests, reading rate assessments and scores for prosodic reading. Based on Table 7, it is clear that on average, the participants made steady progress in terms of their word recognition skill, reading rate and prosody in reading post-intervention. Although S1 was only making borderline progress in all the three major aspects of the reading skill, she did make notable improvement in her overall oral reading fluency after being exposed to the intervention for two cycles. Moreover, constructive feedbacks were also collected during the group interview, where participants were in favour of the research-based practice of re-reading the passages in the graded readers, only that there were suggestions to have more options of reading materials.

\section{Conclusions}

Among all the repeated reading strategies recommended, the assisted model has the upper hand due to the integration of the modelling element into the reading intervention. When good accuracy, speed and prosody are modelled, pupils can listen to what proper reading should sound like first-hand and then reproduce what was read to them until fluency is attained. Before pupils can turn into independent readers, there is a need to provide them with scaffolding when they have to learn about materials that are marginally above their present level of ability. Thus, it seems that a combination of repeated readings and passage modelling produces the best result in terms of fluency. In the context of this study, the participants got to listen to the teacher models the reading of the passages from the graded readers before they engaged in the repeated reading process themselves. Another factor that comes into play is the choice of reading materials for the intervention. Graded readers were selected to be used in the reading intervention. They are books specifically written for second language (L2) learners with repetitive vocabulary and controlled linguistic structures for comfortable reading and accessible content would keep the L2 learners engaged in reading. Therefore, graded readers with its appealing graphics, well-contrasted font colour and legible texts, carefully-planned layout as well as clear storyline with opportunities for direct language learning would be able to counterbalance the dull and tedious side of repeated reading. This was how the struggling readers improved their oral reading fluency with assisted repeated reading using graded readers. Although the results of this study are not conclusive, they are encouraging, especially for ESL educators and struggling readers. This study supports ESL teachers by offering an alternative, or in other words, a different form of reading strategy to help their beginning readers to read in a second language.

\section{Further Suggestions and Research}

One consideration for future research is the feasibility of this reading intervention to be implemented during regular language lessons within the classroom context. With the time constraint that exists in language classrooms, teachers do not have time to facilitate the reading process of individual pupils, especially in a large class. As such, ESL teachers have to devise a plan to execute this intervention. One of the techniques is subsuming the element of peer reading routine as part of the intervention. This notion is validated by the incidental findings from the group interview where the majority of the participants do approve of the peer teaching and learning that happened during the repeated reading sessions. During formal instructional time, pairing less fluent reader with more fluent reader for reading activity could be a better alternative. Given training and if carried out with fidelity, the adapted version of assisted repeated reading using graded readers, that is based on peer reading principles, might be successfully implemented within a formal classroom context.

Next, the original action plan was for all the readers in one group setting for the whole intervention period. As such, the participants who progressed faster than the rest felt bored during the repeated reading sessions in the study. Therefore, after implementing the reading intervention for the first cycle, teachers can further categorise the pupils who can already self-regulate their reading and the ones who need further assistance into two different groups. The former would start with a new set of books while the latter would continue to read the current set of graded readers until sufficient fluency and accuracy are achieved. In this case, the teacher can choose to either have separate intervention sessions to accommodate the needs of the readers or hire the help of another ESL teacher with similar expertise to conduct the sessions simultaneously.

Another recommendation is to limit the duration of each reading session and extend the intervention period into a duration deemed appropriate and convenient for classroom practice. The word recognition, mastery of new vocabulary and other language gains from repeated reading sessions are still fragile. These new skills need to be consolidated even after the intervention period has ended through consistent exposure to the reading materials and sustained implicit learning because the advantages of these reading 
practices are more apparent in the long run (Grabe, 2010). Hence, it is advisable to carry out the intervention for at least 3 months for the maximum impact so that pupils can retain the linguistic knowledge and skills acquired in the long run.

The final suggestion would be for other researchers to address the impact of the reading intervention on the reading comprehension of struggling second language readers. The overall findings of this present study propounded that the reading intervention was well-received with positive outcomes and the review of literature in this area of interest indicated that there exists a meaningful relationship between reading fluency and comprehension. A number of other studies do support the presence of significant relationship between both reading components (Reichert 2019; Roundy \& Roundy 2009; Stevens, Walker \& Vaughn 2016; Therrien 2004). In essence, the objective inference would be that fluent reading can lead to better comprehension because when one can read with spontaneity, accuracy and prosody, this automatic response will allow more mental space for text comprehension to take place. Nevertheless, future research tackling the effect of assisted repeated reading using graded readers on the reading comprehension of struggling second language readers appears warranted.

\section{Appendix A}

\section{Reading Passage from the First Set of Graded Readers}

Peter and Jane like the dog. I like the dog.

Here is Peter and here is Jane. Here is a tree. Jane likes trees and Peter likes trees.
A shop. I like shops. Jane is in a shop and Peter is in a shop. Here is a ball in a shop. Jane likes the ball. Jane has the dog and Jane has the ball. The dog has the ball. The dog likes the ball.

Jane has a shop. Here is Jane's shop. The shop has toys. Jane's shop is a toy shop. Here is a toy dog in Jane's shop. Here is a tree in Jane's shop. Peter is in Jane's shop. The $\operatorname{dog}$ is in the shop.

\section{Appendix B}

\section{Reading Passage from the Second Set of Graded Readers}

Here you are, Jane and Peter. Here is some water. Look in the water. You are in the water. Here is Peter. He likes water. He has the dog. The dog is in the water. He likes it. Jane has a ball. It is for Pat. Pat is here. He wants the ball. Peter wants to jump and Pat wants to jump. They jump for fun. Here is a tree. Pat looks into the tree. He looks for Peter and Jane. They are in the tree.

Here are some sweets. Some are for Peter and some for Jane. They have some sweets. They like sweets.

\section{Appendix C}

\section{Questions for Group Interview}

Open-ended

1. What do you like about the intervention?

2. What do you not like about the intervention? 


\section{Appendix D}

\section{Prosody Rubric}

\begin{tabular}{|c|c|c|c|c|}
\hline & 1 & 2 & 3 & 4 \\
\hline $\begin{array}{l}\text { Expression } \\
\text { and Volume }\end{array}$ & $\begin{array}{l}\text { Reads in a } \\
\text { quiet voice as } \\
\text { if to get words } \\
\text { out. The } \\
\text { reading does } \\
\text { not sound } \\
\text { natural like } \\
\text { talking to a } \\
\text { friend. }\end{array}$ & $\begin{array}{l}\text { Reads in a quiet } \\
\text { voice. The } \\
\text { reading sounds } \\
\text { natural in part of } \\
\text { the text, but the } \\
\text { reader does not } \\
\text { always sound like } \\
\text { they are talking to } \\
\text { a friend. }\end{array}$ & $\begin{array}{l}\text { Reads with volume } \\
\text { and expression. } \\
\text { However, } \\
\text { sometimes the } \\
\text { reader slips into } \\
\text { expressionless } \\
\text { reading and does } \\
\text { not sound like they } \\
\text { are talking to a } \\
\text { friend. }\end{array}$ & $\begin{array}{l}\text { Reads with varied } \\
\text { volume and } \\
\text { expression. } \\
\text { The reader sounds } \\
\text { like they are talking } \\
\text { to a friend with their } \\
\text { voice matching the } \\
\text { interpretation of the } \\
\text { passage. }\end{array}$ \\
\hline Phrasing & $\begin{array}{l}\text { Reads word- } \\
\text { by-word in a } \\
\text { monotone } \\
\text { voice. }\end{array}$ & $\begin{array}{l}\text { Reads in two or } \\
\text { three word } \\
\text { phrases, not } \\
\text { adhering to } \\
\text { punctuation, } \\
\text { stress and } \\
\text { intonation. }\end{array}$ & $\begin{array}{l}\text { Reads with a } \\
\text { mixture of run-ons, } \\
\text { mid sentence } \\
\text { pauses for breath, } \\
\text { and some } \\
\text { choppiness. There } \\
\text { is reasonable stress } \\
\text { and intonation. }\end{array}$ & $\begin{array}{l}\text { Reads with good } \\
\text { phrasing; adhering } \\
\text { to punctuation, } \\
\text { stress and } \\
\text { intonation. }\end{array}$ \\
\hline Smoothness & $\begin{array}{l}\text { Frequently } \\
\text { hesitates and } \\
\text { repeats words } \\
\text { or phrases. } \\
\text { The reader } \\
\text { makes } \\
\text { multiple } \\
\text { attempts to } \\
\text { read the same } \\
\text { passage. }\end{array}$ & $\begin{array}{l}\text { Reads with } \\
\text { extended pauses } \\
\text { or hesitations. } \\
\text { The reader has } \\
\text { many "rough } \\
\text { spots." }\end{array}$ & $\begin{array}{l}\text { Reads with } \\
\text { occasional breaks } \\
\text { in rhythm. The } \\
\text { reader has } \\
\text { difficulty with } \\
\text { specific words } \\
\text { and/or sentence } \\
\text { structures. }\end{array}$ & $\begin{array}{l}\text { Reads smoothly } \\
\text { with some breaks, } \\
\text { but self-corrects } \\
\text { with difficult words } \\
\text { and/ or sentence } \\
\text { structures. }\end{array}$ \\
\hline Pace & $\begin{array}{l}\text { Reads slowly } \\
\text { And } \\
\text { laboriously. }\end{array}$ & $\begin{array}{l}\text { Reads moderately } \\
\text { slowly. }\end{array}$ & $\begin{array}{l}\text { Reads with an } \\
\text { uneven mixture of } \\
\text { fast and slow pace. }\end{array}$ & $\begin{array}{l}\text { Consistently reads at } \\
\text { conversational pace; } \\
\text { appropriate rate } \\
\text { throughout reading. }\end{array}$ \\
\hline
\end{tabular}

Scores of $\mathbf{1 0}$ and more indicated that the reader is making good progress. (Above Minimum)

Scores below 10 meant the reader needs additional instruction and modeling in prosodic reading. (Below Minimum)

\section{REFERENCES}

[1] Ariffin, A. Z., \& Said, N. E. M. (2018). The Use of Incremental Rehearsal in Building Sight Words Acquisition on Struggling Esl Readers. In Badusah, J. \& Kamrozzaman, N. A. (Eds), Proceedings of Seminar Pendidikan Transdisiplin (STEd 2018) (pp. 359-365). Universiti Kebangsaan Malaysia.

[2] Bendak, L. (2018). Effects of Applying Repeated Readings

Method on Reading Fluency and Passage Comprehension of Slow Learners. Middle East Journal of Family Medicine, 16 (1), 232-37. https://doi.org/10.5742/MEWFM.2018.93226

[3] Chall, J. S. (1983). Stages of Reading Development. New York: McGraw-Hill Book Company.

[4] Chomsky, C. (1976). After Decoding: What? Language Arts, 3, 288-296. https://bit.ly/2MxdeG4

[5] Day, R. R. (2018). Extensive Reading. The TESOL Encyclopedia of English Language Teaching. https://doi.org/10.1002/9781118784235.eelt0472 
[6] Dlugosz, D. W. (2000). Rethinking the role of reading in teaching a foreign language to young learners. English Language Teaching Journal, 54(3), 284-290. https://doi.org/ $10.1093 / \mathrm{elt} / 54.3 .284$

[7] EF Education First. (2018). EF English Proficiency Index. Retrieved from https://bit.ly/2MtJ1re

[8] Fields, J. L. (2019). The Effect of Repeated Reading on Accuracy, Fluency, and Comprehension. Thesis Degree of Master of Education. Goucher College.

[9] Frey, N., \& Fisher, D. (2017). Addressing Unintended Instructional Messages About Repeated Reading. The Reading Teacher, 71(3). https://doi.org/71. $10.1002 /$ trtr. 1617

[10] Grabe, W. (2010). Fluency in reading-Thirty-five years later. Reading in a Foreign Language. 22(1):71-83. http://nflrc.hawaii.edu/rfl

[11] Hasbrouck, J., \& Tindal, G. A. (2006). Oral Reading Fluency Norms: A Valuable Assessment Tool for Reading Teachers. The Reading Teacher 59(7): 636-644. https://doi.org/ 10.1598/RT.59.7.3

[12] Hill, D. R. (2001). Survey: Graded readers. ELT Journal 55(3), 300-324. https://doi.org/ 10.1093/elt/55.3.300

[13] Hoon, O. P., Tee, O. P., Liu, O. P., Persad, C., Liang, W. L. B., \& Lisen, W. J. (2015). The use of ubiquitous bottle caps as concrete aids to learn to read and spell for struggling readers. Asia Pacific Journal of Developmental Differences, 2(2), 132-143. https://doi.org/ 10.3850/S2345734115000253

[14] Jalaludin, A. M., \& Hashim, H. (2019). Synthetic Phonics Instruction for Struggling Young ESL Readers: A Review on Benefits and Limitations. In Hassan, K. A. \& Yusof, N. M. (Eds), Paper presented in KOLOPEN Kolukium Pendidikan (pp. 7-15). IPGK Perempuan Melayu

[15] Keat, O. B., \& Ismail, K. (2011). The Remediation of Pass Cognitive Processing in Helping Children with Reading Difficulties.

[16] British Journal of Humanities and Social Sciences, 2(1), 104-120. https://bit.ly/3bLEXLO

[17] Kuhn, M. R., Schwanenflugel, P. J., \& Meisinger, E. B. (2010). Aligning theory and assessment of reading fluency: Automaticity, prosody, and definitions of fluency. Reading Research Quarterly, 45(2), 230-251. https://doi.org/10.1598 /RRQ.45.2.4

[18] LaBerge, D., \& Samuels, S. J. (1974). Toward a theory of automatic information processing in reading. Cognitive Psychology, 6, 293-323. https://bit.ly/2EX1rdI

[19] Lee, J., \& Yoon, S. Y. (2015). The Effects of Repeated Reading on Reading Fluency for Students with Reading Disabilities: A Meta-Analysis. Journal of learning disabilities, 50(2), 213-224. https://doi.org/10.1177/002221 9415605194

[20] Luke, A. (2014). On Explicit and Direct Instruction. https://www.alea.edu.au/ documents/item/861

[21] Maarof, N., \& Yamat, H. (2010). A differentiated classroom approach for diverse ESL readers. International Journal of Learner Diversity, 2(1), 75-86.https://appsmu.ukm.my/erep
[22] McHugh, M. L. (2012). Interrater reliability: the kappa statistic. Biochem Med (Zagreb), 22(3), 276-282. https://www.ncbi.nlm.nih.gov/pmc/articles/PMC390.52/

[23] McLeod, S. (2015). Skinner - Operant Conditioning. SimplyPsychology.

[24] http://www.simplypsychology.org/operant-conditioning.ht $\mathrm{ml}$

[25] Miller, J. M., \& McKenna, M. C. (2016). World Literacy: How Countries Rank and Why It Matters. Routledge.

[26] Ministry of Education Malaysia. (2013). Malaysian Education Blueprint 2015-2025.

[27] Morrow, L. M., Wixson, K. K., \& Shanahan, T. (2013). Teaching with the Common Core Standards for English language arts. Guilford Press.

[28] Namaziandost, E., Nasri, M., \& Esfahani, F. R. (2019). Texts with Various Levels of Hardness, Reading Comprehension and Reading Motivation. Journal of English Language Teaching, 8(1), 60-77. http://journal.unnes.ac.id/sju/index.p $\mathrm{hp} / \mathrm{elt}$

[29] Nation, P. (2018). Reading a whole book to learn vocabulary. International Journal of Applied Linguistics, 169(1), 30-43. https://doi.org/10.1075/itl.00005.nat

[30] Nation, P., \& Ming-Tzu, W. K. (1999). Graded Readers and Vocabulary. Reading in a Foreign Language, 12(2), 355-380. http://nflrc.hawaii.edu/rfl/PastIssues/rfl122nation.pdf

[31] Ozernov-Palchik, O., Norton, E. S., Wang, Y., Beach, S. D., Zuk, J., Wolf, M., Gabrieli, J. D. E., \& Gaan, N. (2018). The relationship between socioeconomic status and white matter microstructure in pre-reading children: A longitudinal investigation.

[32] Hum Brain Mapp, 1-14. https://doi.org/10.1002/hbm.24407

[33] Penner-Wilger, M. (2008). Reading Fluency: A Bridge from Decoding to Comprehension. https://bit.ly/2wIec $7 y$

[34] Protacio, M. S., \& Jang, B. G. (2016). ESL Teachers' Perceptions About English Learners' Reading Motivation. Literacy Research: Theory, Method, and Practice, 65(1), 166-181. https://doi.org/10.1177/2381336916661532

[35] Rasinski, T. V. (2011). Assessing reading fluency. Pacific Resources for Education and Learning.

[36] Rasinski, T. V., Reutzel, D. R., Chard, D., \& Linan-Thompson, S. (2011). Reading fluency. In Kamil, M. L., Pearson, P. D., Moje,

[37] E. B. \& Afflerbach, P. P. (Eds.), Handbook of reading research, 4, 286-319. Routledge.

[38] Reichert, C. R. (2019). The implementation and effectiveness of Tier 2 Response to Intervention reading comprehension in $4^{\text {th }}$ grade. Thesis for Master of Arts in Special Education, Department of Interdisciplinary and Inclusive Education, Rowan University. https://rdw.rowan.edu/etd/2683

[39] Roundy, A. R., \& Roundy, P. (2009). The effect of repeated reading on student fluency: Does practice always make 
perfect?. International Journal of Social, Behavioral, Educational, Economic, Business and Industrial Engineering, 3(9), 1821-1826.http://scholar.waset.org/1999 $.10 / 15850$

[40] Sarroub, L. K., \& Pernicek, T. (2016). Boys, Books, and Boredom: A Case of Three High School Boys and Their Encounters with Literacy, Reading \& Writing Quarterly, 32(1), 27-55. https://doi.org/10.1080/10573569.2013.85905 2

[41] Stevens, E. A., Walker, M. A., \& Vaughn, S. (2016). The Effects of Reading Fluency Interventions on the Reading Fluency and Reading Comprehension Performance of Elementary Students with Learning Disabilities: A Synthesis of the Research from 2001 to 2014. Journal of Learning Disabilities, 50(5), 576-590. https://doi.org/10.11 $77 / 0022219416638028$

[42] Therrien, W. J. (2004). Fluency and comprehension gains as a result of repeated reading: A meta-analysis. Remedial and Special Education, 25(4), 252-261. doi:10.1177/074193250 4025004080

[43] Treiman, R. (2018). Teaching and Learning Spelling. Child Development Perspectives. 12. https://doi.org/10.1111/cdep. 12292

[44] UNESCO Institute for Statistics. (2019). UNESCO eAtlas of Literacy. Retrieved from http://on.uis.unesco.org/literacy-m ap
[45] Vechten, D. V. (2013). Impact of Home Literacy Environments on Students from Low Socioeconomic Status Backgrounds. Thesis for MS in Literacy, School of Arts and Sciences, St. John Fisher College.http://fisherpub.sjfc.edu/e ducation_ETD_masters $/ 248$

[46] Wolf, G. M. (2018). Developing Reading Automaticity and Fluency: Revisiting What Reading Teachers Know, Putting Confirmed Re-search into Current Practice. Creative Education, 9, 838-855. https://doi.org/10.4236/ce.2018.960 62

[47] Wolf, G. M., \& Katzir-Cohen, T. (2001). Reading fluency and its intervention. Scientific Studies of Reading, 5(3), 211-239. https://doi.org/10.1207/S1532799XSSR0503_2

[48] Young, C., Rasinski, T., \& Mohr, K. (2015). Read Two Impress. The Reading Teacher, 69(6), 633-636. https://doi.org/10.1002/trtr.1391

[49] Zhao, H., \& Poole, F. J. (2017). Developing Literacy Skills in the Chinese Dual Language Immersion Classroom. Perspectives on Effective Teaching in DLI and Foreign Language Classrooms, 2, 61-72. https://bit.ly/2ULt6qT

[50] Zimmerman, B. S., Rasinski, T. V., Was, C. A., Rawson, K. A., Dunlosky, J., Kruse, S. D., \& Nikbakht, E. (2019). Enhancing Outcomes for Struggling Readers: Empirical Analysis of The Fluency Development Lesson. Reading Psychology. https://doi.org/10.1080/02702711.2018.1555365 